\title{
GRAIN YIELD AND MICROBIOLOGICAL QUALITY OF COWPEA PLANTS GROWN UNDER RESIDUAL EFFECT OF SEWAGE SLUDGE FERTILIZATION ${ }^{1}$
}

\author{
PAULO AUGUSTO PEREIRA LOPES ${ }^{2}$, RODINEI FACCO PEGORARO ${ }^{3 *}$, MARCOS KOITI KONDO ${ }^{2}$, SILVÂNIO \\ RODRIGUES DOS SANTOS ${ }^{2}$, LUIZ ARNALDO FERNANDES ${ }^{3}$
}

\begin{abstract}
Cowpea plants produce protein-rich grains and present high yield potential when grown under irrigation and organic fertilization, enabling to substitute part of the mineral fertilizer with sewage sludge, reducing costs and generating environmental benefits. Thus, a field study about residual effect of sewage sludge fertilization on cowpea was developed to evaluate this substitution. The experiment was conducted using a randomized block design with four replications, in a $2 \times 5$ factorial arrangement consisted of two fertilization types (residual effect of sewage sludge fertilization, and mineral fertilizers) and five cowpea cultivars (BRS-Pajeu, BRS-Xiquexique, BRS-Marataoa, BRS-Pujante, and BRS-Cauame). The residual fertilizations were from applications of sewage sludge and NPK mineral fertilizers for pineapple crops grown in the area before the cowpea crop. The experiment was conducted using 80,000 plants ha $^{-1}$ and micro-sprinkler irrigation. Vegetative and yield components, grain yield, and microbiological quality were analyzed. BRSPujante had the highest cowpea grain yield $\left(4,124 \mathrm{~kg} \mathrm{ha}^{-1}\right)$ and the highest means for vegetative and yield components. The soil with residual sewage sludge fertilization improved the cowpea root growth and grain yield $\left(3,854 \mathrm{~kg} \mathrm{ha}^{-1}\right)$; the latter was $19 \%$ higher than that of treatments with mineral fertilization. These results were related to the great soil organic matter content provided by the sludge fertilization, which promotes nutrient mineralization, increasing grain yield. Fresh and dry grains of cowpea plants grown under residual effect of sewage sludge fertilization have similar microbiological quality to those of plants grown under mineral fertilization.
\end{abstract}

Keywords: Vigna unguiculata (L). Biosolid. Coliform. Plant nutrition.

\section{PRODUÇÃO E QUALIDADE MICROBIOLÓGICA DE CULTIVARES DE FEIJÃO-CAUPI APÓS ADUBAÇÃO RESIDUAL COM LODO DE ESGOTO}

\begin{abstract}
RESUMO - O feijão-caupi é um cereal rico em proteínas que apresenta elevado potencial produtivo quando cultivado com irrigação e adubação orgânica, sendo possível substituir parte dos fertilizantes minerais pelo lodo de esgoto, com redução de custos e vantagens ambientais. Para avaliar essa substituição, desenvolveu-se um estudo da adubação residual com lodo de esgoto em feijoeiros cultivados no campo, no delineamento em blocos casualizados com quatro repetições, em esquema fatorial $2 \times 5$, correspondendo a dois tipos de adubação (efeito residual do lodo de esgoto ou fertilizantes minerais), e cinco cultivares de feijão-caupi (BRS Pajeú, BRS Xiquexique, BRS Marataoã, BRS Pujante e BRS Cauamé). A adubação residual foi caracterizada pela aplicação de lodo e fertilizantes minerais NPK no cultivo antecessor (abacaxizeiro) ao feijão-caupi. As parcelas foram cultivadas com 80.000 plantas ha $^{-1}$ de feijão-caupi, sendo irrigadas com microaspersão. Foram caracterizados os componentes vegetativos, componentes de produção e a produtividade dos feijoeiros, além da qualidade microbiológica. A cultivar BRS Pujante apresentou maiores médias para os componentes vegetativos e reprodutivos implicando em maior produtividade de grãos, com $4.124 \mathrm{~kg} \mathrm{ha}^{-1}$. O solo adubado com lodo de esgoto propiciou maior crescimento radicular e produtividade de feijão-caupi $\left(3.854 \mathrm{~kg} \mathrm{ha}^{-1}\right), 19 \%$ superior àqueles que receberam somente adubação mineral residual. Esses resultados foram atribuídos ao maior teor de matéria orgânica no solo adubado com lodo, propiciando ambiente favorável para a mineralização de nutrientes e maior produção de grãos. Os grãos verdes e secos de feijão-caupi produzidos após a adubação com lodo de esgoto apresentam qualidade microbiológica semelhante àqueles obtidos no cultivo com adubação mineral.
\end{abstract}

Palavras-chave: Vigna unguiculata (L). Biossólido. Coliformes. Nutrição de plantas. 


\section{INTRODUCTION}

Cowpea (Vigna unguiculata), also known as black eyed pea in the USA, is traditionally known as Gorutubano bean in the semiarid region of the state of Minas Gerais, Brazil; it presents high yield potential when grown under ideal conditions of soil fertilization and water availability, and when is from a good genetic material (BRITO et al., 2012; MONTEIRO et al., 2012). Cowpea is typically grown by family farmers; it is an excellent source of proteins, essential amino acids, carbohydrates, vitamins, and minerals, mainly for low-income populations (SILVA et al., 2018a; CONAB, 2018).

The Brazilian cowpea production in the $2017 / 2018$ crop seasons was $863,200 \mathrm{Mg}$ (equivalent to $25.4 \%$ of the common bean production), over an area of 1,533,100 hectares, presenting yield of 563 $\mathrm{kg} \mathrm{ha}^{-1}$ (CONAB, 2018). The state of Minas Gerais had a production of $7,700 \mathrm{Mg}$, with mean yield of $551 \mathrm{~kg} \mathrm{ha}^{-1}$ (CONAB, 2018). These results show its low mean yield in Brazil and in Minas Gerais when compared to its productive potential, which can reach more than 4,000 $\mathrm{kg} \mathrm{ha}^{-1}$ (SILVA et al., 2018b). This is probably due to the use of low technological level (MONTEIRO et al., 2012), unbalanced fertilization, and non-adapted cultivars to the local conditions.

Several factors affect the cowpea plant growth and yield, such as environmental and genetic conditions (LOCATELLI et al., 2014) and irrigation (BLANCO et al., 2011; SANTOS, 2011) and mineral and organic fertilization managements (BRITO et al., 2012), considering that fertilization stimulates nitrogen fixation by Rhizobium sp. in symbiosis with cowpea plants (PAMPANA et al., 2017). Therefore, fertilization management strategies are necessary to maintain the productivity of agricultural areas, and a sustainable alternative is the use of sewage sludge as soil fertilizer and conditioner (ALBUQUERQUE et al., 2015).

Sewage sludge is a viable alternative nutrient source for plants (ALBUQUERQUE et al., 2015), providing residual effect for succeeding crops because of its slow nutrient release that can last several years (SIEBIELEC; SIEBIELEC; LIPSKI, 2018). This effect can allow a reduction in the consumption of mineral fertilizers and crop implementation costs.

Sewage sludge can be used as soil fertilizer for crops, such as common bean (KUMAR; CHOPRA, 2014), rice (LATARE et al., 2014), sunflower (FREITAS et al., 2012), sugarcane (FRANCO et al., 2010), and wheat (LOBO; GRASSI FILHO; KUMMER, 2014). The application of 100 $\mathrm{Mg} \mathrm{ha}^{-1}$ of sewage sludge resulted in higher grain yield of maize $(521 \%)$, wheat $(129 \%)$, barley (124\%), and rape $(150 \%)$ when compared to crops without this fertilization (SIEBIELEC; SIEBIELEC; LIPSKI, 2018). The residual fertilization from application of $40 \mathrm{Mg} \mathrm{ha}^{-1}$ of sewage sludge to the soil for rice crops resulted in $68 \%$ higher grain yield for the subsequent wheat crops when compared to the treatment with no sewage sludge fertilization, and also in higher yield than the wheat under mineral fertilization (NPK) (LATARE et al., 2014). However, the presence of microbiological contaminants can hinder the application of sewage sludge to the soil for grain and fruit crops that are fresh consumed by humans, mainly when considering the presence of coliforms and thermotolerant microorganisms. The higher contamination risk to plants is soon after the sewage sludge application to the soil, and its exposition to solar radiation during this period can eliminate the contamination risk to grains and fruits.

Microbiological contaminations at harvest and post-harvest can occur due to different factors, especially the inadequate handling of grains, presence of domestic animals, and contamination of transporting equipment, cleaning waters, and packaging. Therefore, greater care is required in agricultural systems that use sewage sludge, mainly at harvesting, application of post-harvest products, and choosing of irrigation system (ALVES et al., 2017).

The main pathogenic agents in sewage sludges that can contaminate cowpea plants are bacteria, protozoa, fungi, virus, and helminths, whose presence and quantity depend on the origin, season of the year, and treatment process used for the sewage sludge (MOTA et al., 2018). Regarding human health, the contamination risk is related to the handling or consumption of inadequately clean fresh foods. Although the cowpea is usually cooked at high temperatures and seldom presents direct microbiological contamination through ingestion.

In this context, the objective of this work was to evaluate the residual effects of fertiization with sewage sludge and mineral fertilization on vegetative characteristics, yield components, and microbiological contamination of irrigated cowpea plants grown under the climatic conditions of the semiarid region of the state of Minas Gerais, Brazil.

\section{MATERIAL AND METHODS}

The study was conducted in the summerautumn period, known as dry crop season, in the municipality of Janaúba, MG, Brazil (15\%43'47.4", $43^{\circ} 19^{\prime} 22.1^{\prime \prime}$, and altitude of $\left.540 \mathrm{~m}\right)$. The climate of the region is Aw, tropical with dry winter, according to the Köppen classification, with average annual rainfall depth of $850 \mathrm{~mm}$ concentrated in November to March. The soil of the experiment area was classified as Oxisol (Latossolo Vermelho Eutrófico; EMBRAPA, 2014). The temperatures during the experiment period are described in Figure 1. 


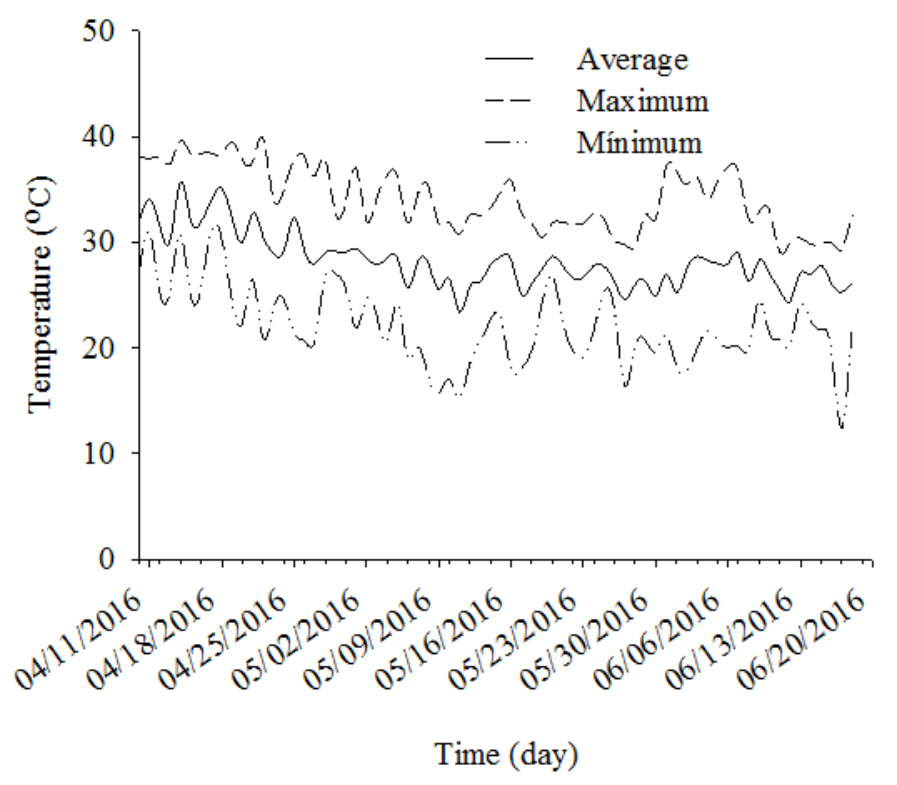

Figure 1. Average, maximum, and minimum air temperatures in the experimental area during the cowpea crop cycle, from April 10 to June $18,2016$.

The experimental area had been used for pastures (low quality and degraded) from 2004 to 2014; then, an experimental pineapple crop was conducted from 2014 to 2016, with application of sewage sludge and mineral fertilizers. $\mathrm{P}_{2} \mathrm{O}_{5}$ (simple superphosphate) were applied at pineapple planting in 2014, at a rate of $3 \mathrm{~g}$ per plant (SOUZA et al., 1999) to all plots. Sewage sludge as applied to the plots at a rate of $2.160 \mathrm{~g}$ per plant, considering a stand of 76,923 plants ha ${ }^{-1}$. The $\mathrm{N}$ demand for the crop development (15 g per plant) was applied according to the results obtained by Cardoso et al. (2013).

The sewage sludge used (Table 1) was from the sewage treatment station of Janaúba, MG, Brazil. The sewage was first treated through a grid and a sand remover, then through a Parshall flume with ultrasonic flow meter, up flow anaerobic sludge blanket (UASB), one facultative pond, and two maturation ponds in series, with treatment capacity with continuous flow of up to $48.4 \mathrm{~L} \mathrm{~s}^{-1}$.

The sewage sludge rate was calculated according to recommendations of the Brazilian National Council for Environment (Resolution 375; CONAMA, 2006), based on its nitrogen contents in mineral form $\left(\mathrm{N}-\mathrm{NH}_{4}^{+}+\mathrm{N}-\mathrm{NO}_{3}{ }^{-}\right)$, and on a mineralizable organic nitrogen fraction of $20 \%$ for anaerobically digested sewage sludge, with application on the soil surface. The plot with mineral fertilizers (NPK) were applied at rate of 15 gplant $^{-1}$ of $\mathrm{N}$ and $\mathrm{K}_{2} \mathrm{O}$, divided into four applications with 60 day intervals (MOTA et al., 2018).

Table 1. Chemical properties of the sewage sludge used in the experimental area.

\begin{tabular}{|c|c|c|c|c|c|c|c|c|c|}
\hline $\begin{array}{l}\mathrm{pH} \\
\mathrm{H}_{2} \mathrm{O}\end{array}$ & ${ }^{1} \mathrm{OC}$ & ${ }^{2} \mathrm{~N}$ & ${ }^{3} \mathrm{P}$ & ${ }^{3} \mathrm{~K}$ & $\begin{array}{r}{ }^{3} \mathrm{Ca} \\
\mathrm{g} \mathrm{kg}^{-1} \\
\end{array}$ & ${ }^{3} \mathrm{Mg}$ & ${ }^{3} S$ & ${ }^{3} \mathrm{Na}$ & \\
\hline 5.4 & 180.0 & 33.0 & 7.6 & 3.2 & 13.0 & 2.3 & 11.8 & 0.1 & \\
\hline${ }^{3} \mathrm{Zn}$ & ${ }^{3} \mathrm{Fe}$ & ${ }^{3} \mathrm{Mn}$ & ${ }^{3} \mathrm{Cu}$ & $\begin{array}{r}{ }^{3} \mathrm{~B} \\
\mathrm{mg} \mathrm{kg}^{-1} \\
\end{array}$ & ${ }^{3} \mathrm{Cd}$ & ${ }^{3} \mathrm{~Pb}$ & ${ }^{3} \mathrm{Cr}$ & ${ }^{3} \mathrm{Ni}$ & $\mathrm{C} / \mathrm{N}$ \\
\hline 950.0 & 24293.0 & 152.0 & 14.0 & 5.8 & 5.2 & 69.1 & 143.2 & 22.1 & 5.5 \\
\hline
\end{tabular}

${ }^{1}$ Organic carbon, Walkley-Black method; ${ }^{2}$ Kjeldahl method; ${ }^{3}$ Total contents extracted by nitro-perchloric solution.

After the pineapple harvest in 2016, the plants were removed from the experimental area, and the cowpea crop was implemented, using the same plots previously treated with sewage sludge and mineral fertilization.

The cowpea experiment was conducted using a randomized block experimental design with four replications, in a $2 \times 5$ factorial arrangement consisted of two fertilization types (residual effect of sewage sludge fertilization SS; and mineral fertilizers MF), and five cowpea cultivars (BRS-Pajeu, BRSXiquexique, BRS-Marataoa, BRS-Pujante, and BRSCauame). The plots had 7 three-meter plant rows and a total area of $6 \mathrm{~m}^{2}$; the three central rows with ten plants per row were considered for evaluation. The characteristics of the cultivars used in the study are described in Table 2. 
P. A. P. LOPES et al.

Table 2. Agronomical characteristics of the cowpea cultivars used in the study.

\begin{tabular}{|c|c|c|c|c|c|c|}
\hline Cultivar & $\begin{array}{l}\text { Commercial } \\
\text { class }\end{array}$ & $\begin{array}{l}\text { Growth } \\
\text { habit }\end{array}$ & $\begin{array}{l}100 \text {-grain } \\
\text { weight }(\mathrm{g})\end{array}$ & $\begin{array}{c}\text { Pod } \\
\text { length } \\
(\mathrm{cm})\end{array}$ & $\begin{array}{c}\text { Mean } \\
\text { grain yield } \\
\left(\mathrm{kg} \mathrm{ha}^{-1}\right)^{*}\end{array}$ & $\begin{array}{l}\text { Recommended } \\
\text { region(Brazil) }\end{array}$ \\
\hline BRS-Pujante & Sempre-verde & Semi-prostate & 24.8 & 18.4 & 1057.0 & São Francisco Valley \\
\hline BRS-Pajeu & Mulato & Semi-prostate & 21.0 & 21.4 & 1035.0 & $\begin{array}{l}\text { North, Northeast, } \\
\text { and Central-West }\end{array}$ \\
\hline $\begin{array}{l}\text { BRS- } \\
\text { Xiquexique }\end{array}$ & Branco & Semi-prostate & 16.5 & 20.0 & 1254.0 & $\begin{array}{l}\text { North, Northeast, } \\
\text { and Central-West }{ }^{1}\end{array}$ \\
\hline $\begin{array}{l}\text { BRS- } \\
\text { Marataoa }\end{array}$ & Sempre-verde & Semi-prostate & 15.5 & 18.0 & 831.0 & $\begin{array}{c}\text { States of Piauí, } \\
\text { Paraíba, and Bahia }\end{array}$ \\
\hline BRS-Cauame & Branco & Semi-ereto & 17.0 & 17.2 & 1060.0 & $\begin{array}{l}\text { North, Northeast, } \\
\text { and Central-West }{ }^{1}\end{array}$ \\
\hline
\end{tabular}

* General mean of assays for the register of the cultivar; ${ }^{1}$ Cultivar recommended for specific states.

The soil preparation consisted of manual cleaning and furrowing. The cowpea seeds were sowed on 03/10/2016 using a manual seeder, considering a depth of 3 to $4 \mathrm{~cm}$, spacing of $0.5 \mathrm{~m}$ between rows and $0.25 \mathrm{~m}$ between plants, and a density of 8 plants $\mathrm{m}^{-2}$.

A mineral fertilization for the cowpea crop was done after a soil chemical analysis (Table 3)at the end of the pineapple crop, according to the recommendations of Andrade Júnior et al. (2002). In the treatments MF and SS,60 and $20 \mathrm{~kg} \mathrm{ha}^{-1}$ of $\mathrm{P}_{2} \mathrm{O}_{5}$ (simple superphosphate), respectively, were applied in the planting furrows; $21 \mathrm{~kg} \mathrm{ha}{ }^{-1}$ of $\mathrm{K}_{2} \mathrm{O}$ (potassium sulfate) was applied in all treatments, divided into two topdressings at 15 and 25 days after emergence (DAE); and $111 \mathrm{~g} \mathrm{ha}^{-1}$ of Mo (ammonium molybdate) was applied through foliar fertilization between 15 and 25 DAE. The plants were thinned at 10 DAE, keeping 80,000 plants ha ${ }^{-1}$.

Table 3. Chemical attributes in the layers of $0-0.2,0.2-0.4$, and $0.4-0.6 \mathrm{~m}$ of soils under residual fertilization from application of sewage sludge (SS) and mineral fertilizers (MF) before cultivation with cowpea.

\begin{tabular}{|c|c|c|c|c|c|c|}
\hline \multirow{3}{*}{ Attributes } & \multicolumn{6}{|c|}{ Soil layers } \\
\hline & \multicolumn{2}{|c|}{$0-0.2 \mathrm{~m}$} & \multicolumn{2}{|c|}{$0.2-0.4 \mathrm{~m}$} & \multicolumn{2}{|c|}{$0.4-0.6 \mathrm{~m}$} \\
\hline & $\mathrm{SS}$ & $\mathrm{MF}$ & $\mathrm{SS}$ & $\mathrm{MF}$ & $\mathrm{SS}$ & $\mathrm{MF}$ \\
\hline $\mathrm{pH}\left(\mathrm{H}_{2} \mathrm{O}\right)$ & 4.69 & 4.70 & 4.61 & 4.70 & 4.96 & 5.06 \\
\hline${ }^{1} \mathrm{TOC}\left(\mathrm{g} \mathrm{kg}^{-1}\right)$ & 26.40 & 12.30 & 12.40 & 10.30 & 7.20 & 6.87 \\
\hline${ }^{2} \mathrm{P}\left(\mathrm{mg} \mathrm{dm}^{-3}\right)$ & 11.18 & 2.16 & 3.62 & 2.26 & 0.40 & 0.85 \\
\hline${ }^{2} \mathrm{~K}\left(\mathrm{mg} \mathrm{dm}^{-3}\right)$ & 240.00 & 269.40 & 211.20 & 198.80 & 140.90 & 141.80 \\
\hline${ }^{3} \mathrm{Ca}\left(\mathrm{cmol}_{\mathrm{c}} \mathrm{dm}^{-3}\right)$ & 2.28 & 1.63 & 2.11 & 1.61 & 1.93 & 1.84 \\
\hline${ }^{3} \mathrm{Mg}\left(\mathrm{cmol}_{\mathrm{c}} \mathrm{dm}^{-3}\right)$ & 1.20 & 1.30 & 1.07 & 1.01 & 0.84 & 0.92 \\
\hline${ }^{2} \mathrm{Fe}\left(\mathrm{mg} \mathrm{dm}^{-3}\right)$ & 125.70 & 65.10 & 89.90 & 65.80 & 69.70 & 55.90 \\
\hline${ }^{2} \mathrm{Cu}\left(\mathrm{mg} \mathrm{dm}^{-3}\right)$ & 1.19 & 0.90 & 0.77 & 0.90 & 0.87 & 0.76 \\
\hline${ }^{2} \mathrm{Zn}\left(\mathrm{mg} \mathrm{dm}^{-3}\right)$ & 6.80 & 0.91 & 3.53 & 0.91 & 1.17 & 1.65 \\
\hline${ }^{2} \mathrm{Mn}\left(\mathrm{mgdm}^{-3}\right)$ & 65.20 & 51.80 & 51.80 & 41.10 & 51.00 & 59.10 \\
\hline${ }^{4} \mathrm{SB}\left(\mathrm{cmol}_{\mathrm{c}} \mathrm{dm}^{-3}\right)$ & 4.09 & 3.62 & 3.72 & 3.13 & 3.19 & 3.21 \\
\hline${ }^{5} \mathrm{CEC}\left(\mathrm{cmol}_{\mathrm{c}} \mathrm{dm}^{-3}\right)$ & 5.84 & 5.18 & 5.15 & 4.54 & 4.67 & 4.57 \\
\hline${ }^{6} \mathrm{BS}(\%)$ & 70.80 & 70.00 & 72.20 & 68.00 & 69.90 & 70.60 \\
\hline${ }^{7} \mathrm{SD}\left(\mathrm{g} \mathrm{cm}^{-3}\right)$ & 1.58 & 1.67 & 1.62 & 1.65 & 1.65 & 1.66 \\
\hline
\end{tabular}

${ }^{1}$ total organic carbon, oxidation wet basis with external heating; ${ }^{2}$ extracted by Mehlich-1; ${ }^{3}$ extracted by $\mathrm{KCl} 1 \mathrm{~mol} \mathrm{~L}{ }^{-1}$; ${ }^{4}$ Sumof bases; ${ }^{5}$ cation exchange capacity at $\mathrm{pH} 7$; ${ }^{6}$ base saturation; ${ }^{7}$ soil density by the paraffin-coated clod method (DONAGEMA, 2011).

The cowpea crop was irrigated with a microsprinkler system, using emitters with mean flow rate of $58 \mathrm{~L} \mathrm{~h}^{-1}$ (equivalent to $5.2 \mathrm{~mm} \mathrm{~h}^{-1}$ ), irrigation efficiency of $94 \%$, and a two-day irrigation shift, programed weekly up to the pod maturation stage, with the aid of the Irriplus ${ }^{\circledR}$ (2008) program, based on data from a meteorological station at the experimental area. The crop evapotranspiration $\left(\mathrm{ET}_{\mathrm{c}}\right)$ was estimated from the reference evapotranspiration $\left(\mathrm{ET}_{0}\right)$ obtained by the Hargreaves-Samani model and multiplied by the crop coefficient $\left(\mathrm{K}_{\mathrm{c}}\right)$ over the crop cycle.

Manual weeding was done at 15,30 , and 45 DAE. Insect control was done as needed from seeding to harvest ,according to Andrade Júnior et al. (2016), with the aid of a database of approved pesticides by the Brazilian Ministry of Agriculture for cowpea crops (AGROFIT, 2016). The cowpea plants were manual harvested at the physiological maturity of each cultivar.

The number of totally expanded and photosynthetically active leaves per plant (NLP) in 20 plants in the evaluation area of each plot were counted at the beginning of the cowpea flowering. Twenty plants per plot were sampled at harvest (approximately 90 days after sowing) for evaluations of root length (RL)from the ground level to the base of the main root; stem base diameter (SD), measured 
in the lower third of the stem; pod length (PL); 100grain weight $(100 \mathrm{GW})$, using the average of three samples of 100 grains; grain index (GI), by dividing the grain weight of the plot by its pod weight; number of pods per plant (NPP), by counting the pods and dividing by 20 (plants in the evaluation area); grain yield (GY), estimating the total production of the evaluation area of the plot in $\mathrm{kg} \mathrm{ha}$ 1 . The grain moisture was corrected to $13 \%$ for the $100 \mathrm{GW}$ and GY.

The microbiological analysis was done in 25 $\mathrm{g}$ of grains and $25 \mathrm{~g}$ of pods of each plot, using plants at pod filling stage $(60$ DAE $)$ and, subsequently, plants at maturation stage. Samples of pods from the basal, median, and apex regions of branches were collected with sterilized gloves and joint in a single sample for microbiological analysis; the grains were separated from the pods and these samples were placed separately in sterile plastic bags for subsequent analysis.

These sampled grains and pods were evaluated for coliforms at $35^{\circ} \mathrm{C}$ and $45^{\circ} \mathrm{C}$ (thermo tolerant microorganisms) by the most probable number (MPN) (SILVA et al., 2010). The presence of coliforms at $45{ }^{\circ} \mathrm{C}$ was confirmed by inoculation in a Escherichia coli broth, using positive test tubes for the analysis of total coliforms, with incubation at selective temperature of $45^{\circ} \mathrm{C}$ for 48 hours.

The data were subjected to analysis of variance by the $\mathrm{F}$ test, using the Sisvar ${ }^{\circledR}$ program (FERREIRA, 2011) and, when significant $(\mathrm{p} \leq 0.05)$, the means were compared by the Tukey's test, considering the $\mathrm{F}$ test as conclusive for the sources of fertilization. The results related to microbiological evaluation were subjected to descriptive analysis.

\section{RESULTS AND DISCUSSION}

The root length (RL) and grain yield (GY) of the cowpea plants evaluated were significantly affected $(\mathrm{p}<0.05)$ by the isolated factors-cultivars and fertilization (Table 4). The morphological characteristics stem base diameter (SD)and number of leaves per plant (NLP), and the components of production pod length (PL), 100-grain weight $(100 \mathrm{GW})$, grain index $(\mathrm{GI})$, and number of pods per plant (NPP) were affected only by the factor cultivar (Table 4). The interaction between the factors was not significant $(p>0.05)$ for the evaluated characteristics of the cowpea plants.

Table 4. Analysis of variance, with mean squares (MS) for root length (RL), stem base diameter (SD),number of leaves per plant (NLP), pod length (PL), grain index (GI), 100-grain weight (100GW), number of pods per plant (NPP), and grain yield (GY)of cowpea plants of five cultivars after fertilization with sewage sludge and mineral fertilizers.

\begin{tabular}{|c|c|c|c|c|c|c|c|c|c|}
\hline \multirow{3}{*}{ Source of variation } & \multirow{3}{*}{ DF } & \multicolumn{8}{|c|}{ MS } \\
\hline & & $\mathrm{RL}$ & SD & NLP & $\mathrm{PL}$ & GI & 100GW & NPP & GY \\
\hline & & $\mathrm{cm}$ & $\mathrm{cm}$ & & $\mathrm{Cm}$ & $\%$ & $\mathrm{~g}$ & & \\
\hline Block & 3 & $25.2^{\mathrm{ns}}$ & $12.1^{\mathrm{ns}}$ & $4129.2^{*}$ & $8.6^{\mathrm{ns}}$ & $7.5^{\mathrm{ns}}$ & $0.1^{\mathrm{ns}}$ & $114.4^{\mathrm{ns}}$ & $659728.8^{\mathrm{ns}}$ \\
\hline Cultivar (C) & 4 & $1201.6^{* *}$ & $463.8^{* *}$ & $53528.0^{*}$ & $1120.8^{* *}$ & $168.9^{* *}$ & $61.1^{* *}$ & $372.2^{*}$ & $3870008.0^{* *}$ \\
\hline Fertilization (F) & 1 & $518.2^{*}$ & $19.5^{\mathrm{ns}}$ & $59.4^{\mathrm{ns}}$ & $5.9^{\mathrm{ns}}$ & $0.1^{\mathrm{ns}}$ & $2.2^{\mathrm{ns}}$ & $18.0^{\mathrm{ns}}$ & $3879857.2^{* *}$ \\
\hline $\mathrm{C} \times \mathrm{F}$ & 4 & $11.3^{\mathrm{ns}}$ & $29.0^{\mathrm{ns}}$ & $4100.3^{\mathrm{ns}}$ & $1.6^{\mathrm{ns}}$ & $13.9^{\mathrm{ns}}$ & $0.4^{\mathrm{ns}}$ & $31.3^{\mathrm{ns}}$ & $25232.5^{\mathrm{ns}}$ \\
\hline Residue & 27 & 5.9 & 13.4 & 1407.2 & 2.9 & 14.3 & 1.0 & 15.4 & 222488.1 \\
\hline$\overline{\text { Mean }}$ & & 24.8 & 1.6 & 167.0 & 21.6 & 79.7 & 19.8 & 16.0 & 3542.2 \\
\hline $\mathrm{CV}(\%)$ & & 9.8 & 23.0 & 22.5 & 8.0 & 4.7 & 5.0 & 25.4 & 13.3 \\
\hline
\end{tabular}

$\mathrm{DF}=$ degrees of freedom; $* *, *$, and $\mathrm{ns}=$ significant at $1 \%$, at $5 \%$, and not significant by the $\mathrm{F}$ test, respectively. $\mathrm{CV}$ $=$ coefficient of variation.

The cowpea cultivars BRS-Pujante and BRSCauame presented the highest and lowest RL, respectively (Table 5). The cultivar BRS-Cauamehad the lowest $\mathrm{SD}(1.32 \mathrm{~cm})$; the other cultivars had similar SD (1.61 to $1.72 \mathrm{~cm})$. BRS-Xiquexique, BRS -Pujante, and BRS-Pajeu presented the highest NLP, and BRS-Xiquexique stood out with 183 leaves per plant.

Table 5. Root length (RL), stem base diameter (SD), number of leaves per plant (NLP), pod length (PL), grain index (GI), 100 -grain weight $(100 \mathrm{GW})$, number of pods per plant (NPP), and grain yield (GY)of cowpea plants of five cultivars.

\begin{tabular}{lcccccccc}
\hline \multirow{2}{*}{ Cultivar } & RL & SD & NLP & PL & GI & $100 \mathrm{GW}$ & NPP & GY \\
\cline { 2 - 9 } & $\mathrm{cm}$ & $\mathrm{cm}$ & & $\mathrm{cm}$ & $\%$ & $\mathrm{~g}$ & $\mathrm{~kg} \mathrm{ha}^{-1}$ \\
\hline BRS-Pujante & $27.48 \mathrm{a}$ & $1.71 \mathrm{a}$ & $180.00 \mathrm{ab}$ & $25.70 \mathrm{a}$ & $77.60 \mathrm{~b}$ & $24.60 \mathrm{a}$ & $18.00 \mathrm{a}$ & $4124.40 \mathrm{a}$ \\
BRS-Xiquexique & $25.77 \mathrm{~b}$ & $1.64 \mathrm{a}$ & $183.00 \mathrm{a}$ & $22.20 \mathrm{~b}$ & $79.90 \mathrm{~b}$ & $18.50 \mathrm{bc}$ & $17.00 \mathrm{~b}$ & $3917.20 \mathrm{~b}$ \\
BRS-Pajeu & $25.30 \mathrm{~b}$ & $1.61 \mathrm{a}$ & $178.00 \mathrm{~b}$ & $21.00 \mathrm{c}$ & $77.70 \mathrm{~b}$ & $17.90 \mathrm{c}$ & $17.00 \mathrm{~b}$ & $3672.20 \mathrm{~b}$ \\
BRS-Marataoa & $25.43 \mathrm{~b}$ & $1.72 \mathrm{a}$ & $146.00 \mathrm{c}$ & $20.40 \mathrm{~d}$ & $75.80 \mathrm{~b}$ & $19.50 \mathrm{~b}$ & $16.00 \mathrm{c}$ & $3649.70 \mathrm{~b}$ \\
BRS-Cauame & $20.19 \mathrm{c}$ & $1.32 \mathrm{~b}$ & $149.00 \mathrm{c}$ & $18.60 \mathrm{e}$ & $87.50 \mathrm{a}$ & $18.40 \mathrm{bc}$ & $14.00 \mathrm{c}$ & $2347.60 \mathrm{~b}$ \\
\hline
\end{tabular}

Means followed by the same letter in the columns are not different by the Tukey's test at $5 \%$ significance. 
The cultivar BRS-Pujante had the highest means for the morphological characteristics evaluated. The highest root length probably affected the other morphological characteristics of this cultivar, resulting in thick stem and high number of leaves. A more vigorous root system is related to plants with higher water and nutrient absorption capacity (VALADÃO et al., 2015), which increases their photoassimilates production, growth, and development. According to Santos (2011), the cultivar BRS-Pujante is recommended for crop sunder irrigation in the São Francisco Valley, especially in the second half of the year, because it has good productive characteristics, such as large grains and pods.

The highest means for the production components PL $(25.7 \mathrm{~cm}), 100 \mathrm{GW}(24.6 \mathrm{~g})$, and NPP (18 pods plant ${ }^{-1}$ ) were found for BRS-Pujante (Table 5). These production components contributed to its higher grain yield. Its better results for production components are attributed to its higher genetic potential, as described by Santos (2011), who reported that this cultivar presented mean PL of 18.4 $\mathrm{cm}$, and $100 \mathrm{GW}$ of $24.8 \mathrm{~g}$. These results were lower than those found for the cultivar in the present study, which can be related to the use of irrigation and to the residual effects of fertilizations made for the previous crop. Santana et al. (2019) pointed out the genetic divergences between cowpea genotypes and that the pod weight, flowering beginning time, PL, $100 \mathrm{GW}$, and NPP were the characteristics that contributed the most to genetic divergences.

The other cultivars evaluated in the presented study showed similar GY, from 2,347.62 to 3,917.15 $\mathrm{kg} \mathrm{ha}^{-1}$ (Table 5). These grain yields were higher than the Brazilian national mean $\left(563 \mathrm{~kg} \mathrm{ha}^{-1}\right)$ in the 2017/2018 crop season (CONAB, 2018). The climatic conditions of Janaúba, especially the high temperatures (Figure 1), combined with the balanced irrigation and fertilization throughout the cowpea crop cycle favored the crop performance. These results indicate a good adaptation of the evaluated genotypes to the climatic conditions of the North of
Minas Gerais, as described by Silva et al. (2018c). According to Souza et al. (2018), several cowpea cultivars and lines that present satisfactory grain yields and good characteristics of size, lodging, and crop value were recommended for this region of Minas Gerais (lines MNC04-769F-30, MNC05-795F -154, and MNC04-769F-49; and cultivars BRSTumucumaque, BRS-Guariba, BRS-Novaera, BRSItaim, and BRS-Cauame).

The assays conducted for the register of the cultivar BRS-Pujante indicated grain yields of 705.0 $\mathrm{kg} \mathrm{ha}^{-1}$ (under rainfed conditions) and $1979 \mathrm{~kg} \mathrm{ha}^{-1}$ (under irrigation conditions), but without fertilizer applications (SANTOS, 2011). Thus, the use of irrigation combined with mineral fertilization (MF) and residual fertilization from sewage sludge application (SS) shows that the potential grain yield of cowpea is higher in intensive crop systems.

The mean grain yield of the evaluated cultivars was approximately 6.3 times higher than the national mean cowpea grain yield, whose main limitation is the low technological level usually applied to the crop, which is commonly used for subsistence of family farmers (MONTEIRO et al., 2012). Several studies present lower grain yields to those found in Janaúba. This is found for the cultivars BRS-Xiquexique (MATOSO et al., 2013), BRS-Cauame (SANTOS et al., 2016), BRSMarataoa (SILVA; NEVES, 2011), and BRS-Pajeu (LOCATELLI et al., 2014).

The treatments with residual fertilization from application of sewage sludge presented higher RL than those with mineral fertilization (Table 6), probably due to a higher organic matter content and lower soil density in the $0-20 \mathrm{~cm}$ layer (Table 3), which was a favored environment for root development. Thus, higher cowpea GY was found with sewage sludge residual fertilization, with mean of $3,853.7 \mathrm{~kg} \mathrm{ha}^{-1}$, which was $19 \%$ higher than those found in plants under only mineral fertilization, representing an increase of 10.4 60-kilo bags of cowpea grains per hectare (Table 6).

Table 6. Root length (RL), stem base diameter (SD), number of leaves per plant (NLP), pod length(PL), grain index (GI), 100 -grain weight $(100 \mathrm{GW})$, number of pods per plant (NPP), and grain yield (GY) of cowpea plants after fertilization with sewage sludge and mineral fertilizers.

\begin{tabular}{llc}
\hline Fertilization & $\mathrm{RL}$ & $\mathrm{GY}$ \\
\cline { 2 - 3 } & $\mathrm{cm}$ & $\mathrm{kg} \mathrm{ha}^{-1}$ \\
\hline Sewage sludge & $25.64 \mathrm{a}$ & $3853.70 \mathrm{a}$ \\
Mineral fertilizers & $24.03 \mathrm{~b}$ & $3230.80 \mathrm{~b}$ \\
\hline
\end{tabular}

Means followed by the same letter in the columns are not different by the F test at $5 \%$ significance.

Applications of sewage sludge to agricultural soils have provided a positive residual effect in the production of crops. Residual fertilization of sewage sludge in wheat crops after rice crops provided $68 \%$ higher GY, with the application of
$30 \mathrm{Mg} \mathrm{ha}^{-1}$ resulting in similar GY to those found in the treatment with NPK mineral fertilization (LATARE et al., 2014). Lobo, Grassi Filho and Kummer (2014) found positive residual effects of sewage sludge fertilization in GY of wheat in the 
second year of growing, after application of approximately $44 \mathrm{Mg} \mathrm{ha}^{-1}$ of sewage sludge. The use of organic fertilization combined with irrigation resulted in $54 \%$ higher GY $\left(1,422.5 \mathrm{~kg} \mathrm{ha}^{-1}\right)$ for cowpea plants of the cultivar BRS-Pujante intercropped with maize, when compared to the control treatment (BRITO et al., 2012). Soil fertilization with sewage sludge presents longer organic compound mineralization and nutrient availability, resulting in residual effects for several crop cycles, reducing production costs (ALBUQUERQUE et al., 2015). It also increases the soil microbial and enzymatic activity, as found by Siebielec, Siebielec and Lipski (2018), who reported that sewage sludge applications over six years favored the enzymatic activity (phosphatases and dehydrogenases), which was stimulated by the higher number of microorganisms in the soil, resulting in higher grain yields for maize, wheat, and barley crops when compared to crops under only NPK fertilization

The highest GY found for the cultivars under residual fertilization of sewage sludge was attributed to the improvement of soil chemical and physical characteristics, mainly by the increase in organic matter and decrease in soil density (Table 3), which contribute for higher availability of nutrients, especially nitrogen, since this element limits cowpea grain yield because it is the most extracted nutrient by the crop (TAGLIAFERRE et al., 2013). The nitrogen in the sewage sludge is predominantly organic (PIRES et al., 2015), and is gradually mineralized over time and made available to plants (ZARE; RONAGHI, 2019). Thus, nitrogen can be kept longer in soils fertilized with sewage sludge than in soils fertilized with high-solubility fertilizers, which results in increases in grain yield.

No contamination by total coliforms (MPN $\mathrm{g}^{-1}<3$ ) and thermotolerant microorganisms (MPN $\mathrm{g}^{-1}<3$ ) was found in fresh grains of any plants at pod filling stage (60 days after sowing) (Table7). However, contamination of fresh pods was found in plants of the cultivars BRS-Pujante, BRSCauame, and BRS-Pajeu in the treatments with SS, and in plants of BRS-Cauame, BRS-Xiquexique and BRS-Pajeu in the treatments with MF (Table7). Therefore, contamination was found in cowpea fresh pods in the treatments with SS and MF.

The means of total and thermotolerant coliforms found in fresh pods varied from $<3$ to $>$ 1,000 MPN ge in plants in the treatments with SS, and $<3$ to $11 \mathrm{MPN} \mathrm{g}^{-1}$ in plants in treatments with MF. This contamination was attributed to the semiprostate growth habit of plants of the cultivars BRSPujante, BRS-Pajeu, and BRS-Xiquexique (Table 2), which allowed the fresh pods in the lower parts of the plant to have contact with the soil. These results also indicate the possibility of contamination of humans by the handling of fresh pods, which may be a risk to human health, denoting the need for use of personal protection equipment during the harvest and for microbiological cleaning of fresh pods for human consumption. However, this contamination did not occur internally and did not affect the grains.

The BRS-Cauame cultivar, which has semierect growth habit (Table 2) also presented contamination in fresh pods (Table 7). This was probably due to the presence of animals in the experimental area, especially birds and insects, which were frequently seen in the site and over the plant pods.

Table 7. Microbiological analysis of fresh and dry pods and grains of plants of five cowpea cultivars at 60 and 90 days after emergence (pod filling stage and maturation stages, respectivelly), after fertilization with sewage sludge and mineral fertilizers.

\begin{tabular}{|c|c|c|c|c|c|c|c|c|}
\hline \multirow{3}{*}{ Cultivar } & \multicolumn{2}{|c|}{ Sewage sludge } & \multicolumn{2}{|c|}{ Mineral } & \multicolumn{2}{|c|}{ Sewage sludge } & \multicolumn{2}{|c|}{ Mineral } \\
\hline & $\overline{\mathrm{TC}}$ & TTC & $\mathrm{TC}$ & TTC & $\mathrm{TC}$ & TTC & $\mathrm{TC}$ & TTC \\
\hline & \multicolumn{8}{|c|}{$\mathrm{MPN} \mathrm{g}^{-1}$} \\
\hline & \multicolumn{8}{|c|}{60 days after emergence (pod filling stage) } \\
\hline & \multicolumn{2}{|c|}{ Fresh grain } & \multicolumn{2}{|c|}{ Fresh grain } & \multicolumn{2}{|c|}{ Fresh pod } & \multicolumn{2}{|c|}{ Fresh pod } \\
\hline BRS-Pujante & $<3.0$ & $<3.0$ & $<3.0$ & $<3.0$ & $>1100.0$ & $>1100.0$ & $<3.0$ & $<3.0$ \\
\hline BRS-Marataoa & $<3.0$ & $<3.0$ & $<3.0$ & $<3.0$ & $<3.0$ & $<3.0$ & $<3.0$ & $<3.0$ \\
\hline BRS-Cauame & $<3.0$ & $<3.0$ & $<3.0$ & $<3.0$ & $>1100.0$ & 290.0 & 6.1 & $<3.0$ \\
\hline BRS-Xiquexique & $<3.0$ & $<3.0$ & $<3.0$ & $<3.0$ & $<3.0$ & $<3.0$ & 11.0 & 11.0 \\
\hline \multirow[t]{3}{*}{ BRS-Pajeu } & $<3.0$ & $<3.0$ & $<3.0$ & $<3.0$ & 9.0 & $<3.0$ & 11.0 & 11.0 \\
\hline & \multicolumn{8}{|c|}{90 days after emergence (maturation stage) } \\
\hline & \multicolumn{2}{|c|}{ Dry grain } & \multicolumn{2}{|c|}{ Dry grain } & \multicolumn{2}{|c|}{ Dry pod } & \multicolumn{2}{|c|}{ Dry pod } \\
\hline BRS-Pujante & $<3.0$ & $<3.0$ & $<3.0$ & $<3.0$ & $<3.0$ & $<3.0$ & $<3.0$ & $<3.0$ \\
\hline BRS-Marataoa & $<3.0$ & $<3.0$ & $<3.0$ & $<3.0$ & $<3.0$ & $<3.0$ & $<3.0$ & $<3.0$ \\
\hline BRS-Cauame & $<3.0$ & $<3.0$ & $<3.0$ & $<3.0$ & $<3.0$ & $<3.0$ & $<3.0$ & $<3.0$ \\
\hline BRS-Xiquexique & $<3.0$ & $<3.0$ & $<3.0$ & $<3.0$ & $<3.0$ & $<3.0$ & $<3.0$ & $<3.0$ \\
\hline BRS-Pajeu & $<3.0$ & $<3.0$ & $<3.0$ & $<3.0$ & $<3.0$ & $<3.0$ & $<3.0$ & $<3.0$ \\
\hline Tolerance & \multicolumn{2}{|c|}{500.0} & \multicolumn{2}{|c|}{500.0} & & 500.0 & \multicolumn{2}{|c|}{500.0} \\
\hline
\end{tabular}

$\mathrm{MPN}=$ most probable number; $\mathrm{TC}=$ total coliforms; TTC $=$ thermotolerant coliforms; Tolerance $=$ maximum tolerance to presence of microorganisms allowed by the resolution RDC ${ }^{\circ} 12$ of 02/01/2001 (BRASIL, 2001).

Rev. Caatinga, Mossoró, v. 33, n. 1, p. 21 - 30, jan. - mar., 2020 
The results found in the present study confirm those of Alves et al. (2017), who evaluated microbiological characteristics in banana fruits treated with effluents from the same treatment station and found thermotolerant coliforms and Escherichia coli in banana peels in the control without application of sewage effluent; they attributed this result to birds and bats frequently found over the banana trees in the experimental area.

The contamination indexes of fresh pods of the cultivars BRS-Marataoa, BRS-Xiquexique, and BRS-Pajeuwere below the tolerance limit (500 MPN g ${ }^{-1}$ ) established by the Anvisa (BRASIL, 2001), in all treatments (SS and MF) (Table 7). This was probably due to the plant growth environment, which had high solar radiation and low air humidity and soil moisture during some cowpea growth stages. According to García Orenes et al. (2007), the edaphoclimatic conditions of the semiarid region of the state of Minas Gerais contribute to reduction of coliforms; they evaluated the survival rate of total coliforms in different agricultural soils (with and without irrigation)in this region after incorporation of sewage sludge and found that low air humidity reduces total coliforms in the soil. Different from other bacteria, coliforms present no resistance to absence of irrigation. This denotes that the period with no irrigation ( 8 months) between the pineapple and cowpea crops contributed to the reduction of coliforms in the soil from the fertilization with sewage sludge.

Fresh cowpea pods are commonly discarded, and the grains are consumed after cooking. Oliveira et al. (2008) evaluated the microbiological quality of cowpea grains and found 430 to $100,000 \mathrm{MPN} \mathrm{g}^{-1}$ of total coliforms in raw grains, and $10 \mathrm{MPN} \mathrm{g}^{-1}$ of total coliforms in cooked grains, with or without water at maceration, denoting that the thermal treatment reduced the total coliforms in raw samples.

After the cowpea pod maturation (90 DAE), the contamination by total coliforms (MPN g ${ }^{-1}<3$ ) and thermotolerant microorganisms (MPN g ${ }^{-1}<3$ ) was null in grains and pods of plants in all evaluated treatments (Table 7).

The survival of pathogenic microorganisms in contact with plants depends on environmental factors, because air temperature, solar radiation, and air humidity conditions are commonly unfavored to the pathogen. According to Jang et al. (2017), the survival of microorganisms, including Escherichia coli, is low when they are exposed to abiotic factors, such as high air temperatures $(>30 \mathrm{C})$, high solar radiation, and low air humidity. The harvest of dry pods occurred at more than 10 days after the irrigation was stopped, which probably hindered the presence of pathogenic microorganisms that needed water for their growth and metabolism. Moreover, the edaphoclimatic conditions of the semiarid region of the state of Minas Gerais may have contributed to the reduction of coliforms in the soil.
Currently, the consumers are more concerning about the nutritional value of foods, and absence of toxic elements and microbiological contaminants in them. The present work showed that a food with adequate quality for human consumption was obtained, according to the standards established by the Anvisa (BRASIL, 2001), regardless of the time when the analyses were carried out-at pod filling (fresh grains) and maturation (dry grains) stages.

\section{CONCLUSIONS}

Cowpea plants can be grown in areas with residual fertilization of sewage sludge, which increases their growth and yield. Considering irrigated crops, the cultivar BRS-Pujante is the most productive cowpea cultivar, followed by BRSXiquexique, BRS-Pajeu, and BRS-Marataoa, which present intermediate values for production components; the cultivar BRS-Cauame has lower values for production and vegetative components than the other four cultivars. The residual fertilization of sewage sludge resulted in cowpea fresh and dry grains with similar microbiological quality to those under mineral fertilization, but requiring higher are for human consumption of fresh pods of plants grown in soils that have previous soil fertilization with sewage sludge.

\section{ACKNOWLEDGEMENTS}

The authors thank the Foundation for Research Support of the State of Minas Gerais (FAPEMIG), the Brazilian National Council for Scientific and Technological Development (CNPq), and the Brazilian Coordination for the Improvement of Higher Education Personnel (CAPES; Financial Code 001) for financial support to this research project and grating of scholarships; and the Sanitation Company of Minas Gerais (COPASA) for making available the area to this experiment and for financial support.

\section{REFERENCES}

\author{
AGROFIT 2016. Sistema de agrotóxicos \\ fitossanitários. Disponível em: http:// \\ agrofit.agricultura.org.br/agrofit_cons/ \\ principal agrofit cons. Acesso em: 18 de ago. de \\ 2016.
}

ALBUQUERQUE, H. C. et al. Residual effect of sewage sludge fertilization on sunflower yield and nutrition. Revista Brasileira de Engenharia Agrícola e Ambiental, 19: 1005-1011, 2015. 
ALVES, P. F. S. et al. Banana fertigation with treated sanitary wastewater: postharvest and microbiological quality. Semina: Ciências Agrárias, 38: 1229-1240, 2017.

ANDRADE JÚNIOR, A. S. et al. Cultivo do Feijão -caupi: solos e adubação. Versão Eletrônica. 2002. Disponível em: <https:// www.infoteca.cnptia.embrapa.br>. Acesso em: 20 de jan. 2017.

ANDRADE JÚNIOR, A. S. et al. Atividades Econômicas, Cultivos, Feijão Caupi: Doenças e Pragas. Sistema de Produção Feijão-Caupi, Embrapa Meio Norte. Versão Eletrônica. 2016. Disponível em: <https:// www.agencia.cnptia.embrapa.br>. Acesso em: 20 de ago. 2019.

BLANCO, F. F. et al. Milho verde e feijão-caupi cultivados em consórcio sob diferentes lâminas de irrigação e doses de fósforo. Pesquisa Agropecuária Brasileira, 46: 524-530, 2011.

BRASIL - MINISTÉRIO DA SAÚDE, AGÊNCIA NACIONAL DE VIGILÂNCIA SANITÁRIAResolução RDC no. 12, de 2 de Janeiro de 2001. Aprova regulamento técnico sobre padrões microbiológicos para alimentos. Diário Oficial da República Federativa do Brasil, Brasília, 02 de janeiro 2001. Disponível em: <http:// www.anvisa.gov.br_legisl/>. Acesso em: $10 \mathrm{de} \mathrm{fev.}$ 2017.

BRITO, L. T. L. et al. Produtividade da água de chuva em culturas de subsistência no semiárido pernambucano. Engenharia Agrícola, 32: 102-109, 2012.

CARDOSO, M. M. et al. Crescimento do abacaxizeiro 'Vitória' irrigado sob diferentes densidades populacionais, fontes e doses de nitrogênio. Revista Brasileira de Fruticultura, 35: 769-781, 2013.

COMPANHIA NACIONAL DE ABASTECIMENTO - CONAB. Acompanhamento da safra brasileira de grãos. v. 5, n. 9, 2018.

CONSELHO NACIONAL DO MEIO AMBIENTE - CONAMA. Resolução no 375 de 29 de agosto de 2006. Brasília: Ministério do Meio Ambiente, 2006. Disponível em: <http://www.mma.gov.br/port/ conama/res/res06/res37506.pdf $>$. Acesso em: 21 set. 2019.

DONAGEMA, G .K. et al. Manual de métodos de análise de solo. 2. ed. Rio de Janeiro, RJ: Embrapa Solos, 2011. $230 \mathrm{p}$.
EMPRESA BRASILEIRA DE PESQUISA AGROPECUÁRIA - EMBRAPA. Sistema brasileiro de classificação de solos. 4. ed. Brasília, DF: Embrapa, 2014. 376 p.

FERREIRA, D. F. Sisvar: a computerstatisticalanalysis system. Ciência e Agrotecnologia, 35: 1039-1042, 2011.

FRANCO, A. et al. Sewage sludge as nitrogen and phosphorus source for cane-plant and first ratoon crops. Revista Brasileira de Ciência do Solo, 34: 553-561, 2010.

FREITAS, C. A. S. et al. Crescimento da cultura do girassol irrigado com diferentes tipos de água e adubação nitrogenada. Revista Brasileira de Engenharia Agrícola e Ambiental, 16: 1031-1039, 2012.

GARCÍA ORENES, F. et al. Effect of irrigation on the survival of total coliforms in three semiarid soils after amendment with sewage sludge. Waste Management, 27: 1815-1819, 2007.

IRRIPLUS. Sistema para Manejo de Irrigação, Versão 2.8: UFV/GESAI/CIENTEC - Viçosa, 2008.

JANG, J. et al. Environmental Escherichia coli: Ecology and Public Health Implications-A Review. Journal of applied microbiology, 123: 570-581, 2017.

KUMAR, V.; CHOPRA, A. K. Accumulation and translocation of metals in soil and different parts of French bean (Phaseolus vulgaris L.) amended with sewage sludge. Bulletin of Environmental Contamination and Toxicology, 92: 103-108, 2014.

LATARE, A. M. et al. Direct and residual effect of sewage sludge on yield, heavy metals content and soil fertility under rice-wheat system. Ecological Engineering, 69: 17-24, 2014.

LOBO, T. F.; GRASSI FILHO, H.; KUMMER, A. C. B. Aplicações sucessivas de lodo de esgoto no girassol e efeito residual no trigo e triticale. Revista Brasileira de Engenharia Agrícola e Ambiental, 18: 881-886, 2014

LOCATELli, V. E. R. et al. Componentes de produção, produtividade e eficiência da irrigação do feijão-caupi no cerrado de Roraima. Revista Brasileira de Engenharia Agrícola e Ambiental, 18: 574-580, 2014

MATOSO, A. O. et al. Desempenho agronômico de feijão-caupi e milho semeados em faixas na safrinha. Pesquisa Agropecuária Brasileira, 48: 722-730, 2013. 
MONTEIRO, F. P. R. et al. Efeitos de herbicidas na biomassa e nodulação do feijão-caupi inoculado com rizóbio. Revista Caatinga, 25: 44-51, 2012.

MOTA, M. F. C. et al.Contamination of soil and pineapple fruits under fertilization with sewage sludge. Revista Brasileira de Engenharia Agrícola e Ambiental, 22: 320-325, 2018.

OLIVEIRA, V. R. et al. Nutritional and microbiological quality of common beans (Phaseolus vulgaris L.) cooked with or without the use of soaking water. Ciência e Agrotecnologia, 32: 1912-1918, 2008.

PAMPANA, S. et al. Biosolids differently affect seed yield, nodule growth, nodule-specific activity, and symbiotic nitrogen fixation of field bean. Crop and Pasture Science, 68: 735-745, 2017.

PIRES, A. M. M. et al. Disponibilidade e mineralização do nitrogênio após aplicações sucessivas de lodo de esgoto no solo, estimadas por meio de incubação anaeróbica. Pesquisa Agropecuária Brasileira, 50: 333-342, 2015.

SANTANA, S. R. A. et al. Divergência genética entre genótipos de feijão-caupi por caracteres morfoagronômicos. Revista Caatinga, 32: 841-850, 2019.

SANTOS, A. et al. Adaptability and stability of erect cowpea genotypes via REML/BLUP and GGE Biplot. Bragantia, 75: 299-306, 2016.

SANTOS, C. A. F. Cultivares de feijão-caupi para o Vale do São Francisco. Petrolina, PE: Embrapa Semiárido, 2011, 10 p. (Circular Técnica, 94).

SIEBIELEC, G.; SIEBIELEC, S.; LIPSKI, D. Longterm impact of sewage sludge, digestate and mineral fertilizers on plant yield and soil biological activity. Journal of Cleaner Production, 187: 372-379, 2018.

SILVA, A. C. et al. Diagnóstico da produção de feijão-caupi no nordeste brasileiro. Revista da Universidade Vale do Rio Verde, 16: 1-5, 2018a.

SILVA, J. A. L.; NEVES, J. A. Componentes de produção e suas correlações em genótipos de feijãocaupi em cultivo de sequeiro e irrigado. Revista Ciência Agronômica, 42: 702-713, 2011.

SILVA, J. D. L. et al. Seleção simultânea para desenvolvimento de linhagens de feijão-caupi de porte ereto e do tipo fradinho. Revista Caatinga, 31 : 72-79, 2018b.
SILVA, M. B. O. et al. Desempenho agronômico de genótipos de feijão-caupi. Revista de Ciências Agrárias, 41: 201-210, 2018c.

SILVA, N. et al. Manual de Métodos de Análise Microbiológica de Alimentos e Água. 4. ed. São Paulo, SP: ITAL, 2010. 624 p.

SOUZA, V. B. et al. Desempenho de linhagens elite de feijão-caupi em ambientes de Minas Gerais e Mato Grosso. Revista Caatinga, 31: 90-98, 2018.

SOUZA, M. et al. Abacaxizeiro. In: RIBEIRO, A .C.; GUIMARÃES, P. T. G.; ALVAREZ V., V. H. (Eds.). Recomendações para o uso de corretivos e fertilizantes em Minas Gerais: $\mathbf{5}^{\mathbf{a}}$ Aproximação. Viçosa, MG: CFSEMG, 1999. p. 194 $-194$

VALADÃO, F. C. A. et al. Adubação fosfatada e compactação do solo: sistema radicular da soja e do milho e atributos físicos do solo. Revista Brasileira de Ciência do Solo, 39: 243-255, 2015.

TAGLIAFERRE, C. et al. Características agronômicas do feijão caupi inoculado em função de lâminas de irrigação e de níveis de nitrogênio. Revista Ceres, 60: 242-248, 2013.

ZARE, L; RONAGHI, A. Comparison of $\mathrm{N}$ mineralization rate and pattern in different manureand sewage sludge-amended calcareous soil. Communications in Soil Science and Plant Analysis, 50: 559-569, 2019. 